British \& Irish Botany 3(1): 74-89, 2021

\title{
Scotland's heritage of naturalised medicinal plants
}

\author{
Michael E. Braithwaite \\ Hawick, Scotland
}

Corresponding author: mebraithwaite@btinternet.com

This pdf constitutes the Version of Record published on $16^{\text {th }}$ February 2021

\begin{abstract}
Although much has been written about Scottish plants, there has been no Flora of Scotland as such since Hooker's Flora Scotica of 1821. Instead British Floras and distribution Atlases have been published. When BSBI's New Atlas of the British and Irish Flora was published in 2002, introduced plants were subdivided into archaeophytes and neophytes for Britain as a whole, but British natives that were considered to be introductions in Scotland were not subdivided. As a result the specifically Scottish archaeophyte heritage has been neglected. Taken together, Sutherland's Hortus Medicus Edinburgensis 1683 and Sibbald's Scotia Illustrata 1684 provide a baseline from which to investigate the history of many species now considered to be naturalised introductions in Scotland. This has enabled them to be divided between archaeophytes and neophytes giving perspective to their heritage, particularly that of former medicinal plants. A table of such species is presented with detailed comment.
\end{abstract}

Key words: archaeophyte; neophyte; Edinburgh Physic Garden; James Sutherland; Robert Sibbald.

\section{Introduction}

Over a period of years I have investigated the history of a number of Scottish plants, mainly in connection with my fifty years of fieldwork on the Berwickshire and Roxburghshire floras, some of which are discussed in Living plants from ancient people (Braithwaite, 2014d). Most recently, I have written Patrolling the Scottish Border (Braithwaite, 2020) in which I discuss the history of some species that have migrated north across the Scottish Border.

In BSBI's New Atlas of the British and Irish Flora (Preston et al, 2002), as an innovation, introduced plants were most helpfully subdivided into archaeophytes (introduced before 1500 AD) and neophytes for Britain as a whole. I have been frustrated by this treatment because, as this work encompassed all of Britain and Ireland, British natives that were mapped as introductions in Scotland were not subdivided.

My attention has now been drawn to James Sutherland's Hortus Medicus Edinburgensis (Sutherland, 1683) and Sir Robert Sibbald's Scotia Illustrata (Sibbald, 1684) and it has occurred to me that, taken together, they could provide a baseline to review the history of Scotland's naturalised plants and, in particular, of former medicinal plants. These are very much a part of Scotland's cultural heritage and one that is distinct from the heritage of such plants in England, which has a very 
different history. I have now completed such a review accessing a variety of other sources to supplement the two early floras.

I have taken the view that the status of arable weeds and casuals that might have been introduced into Scotland before $1500 \mathrm{AD}$ are adequately covered by the New Atlas, and have restricted my attention to other species listed by Sutherland (1683) and Sibbald (1684) that are now regarded as naturalised introductions in Scotland. These comprise plants used by man, primarily former medicinal plants, and some purely ornamental species.

\section{Sutherland and Sibbald}

Robert Sibbald (1641-1722) was a physician who quickly became a man of influence in Edinburgh. He cultivated medicinal plants from an early age and soon recruited James Sutherland (1639-1719) to care for his collection. Working with Andrew Balfour the collection was formally established in 1667, was transferred to larger grounds in 1675 as the Edinburgh Physic Garden and in 1699 was moved again on a much larger scale and with increased status as the Royal Botanic Garden Edinburgh, where Sutherland became the first Regius Keeper. Sibbald was intent on following John Ray's Catalogus Plantarum Angliae et insularum adjacentum or 'Catalogue of the Plants of England and the adjacent islands' (Ray, 1670). Sibbald obtained a royal warrant to send out a request for lists of wild plants and animals to suitable individuals all over Scotland (Sibbald, 1682). The response was excellent, given the circumstances in Scotland at the time, and formed much of the basis of his Scotia Illustrata (Sibbald, 1684). It is not without errors and inadequacies, as might be expected given the diverse abilities of the contributors. The book has several sections including Plantis in Scotia sponte nascentibus agit or 'The naturally occurring wild plants of Scotland' and Plantis Scotiae Hortensibus or 'The garden plants of Scotland'. The first of these has recently been translated from the original Latin by Lee Raye (Raye, 2020).

James Sutherland was a highly accomplished botanist and gardener, who, after seven years work, could boast that the Edinburgh Physic Garden ranked with the best in Europe. That this was no idle boast is demonstrated by his meticulous Hortus Medicus Edinburgensis (Sutherland, 1683) which lists about 2,000 plants cultivated in the garden.

In his listing of both wild and garden plants, the emphasis of Sibbald's book is on medicinal and other uses. He lists the 'virtues' of each, not separating his own teaching from the many quotations from various herbals. Some species are listed as 'officinal' plants whether or not specific uses are detailed. I have just accepted that both the species with listed uses and the remaining officinal plants might have been introduced around Scotland in the past.

Sutherland's catalogue is more closely structured. He does not list specific uses but instead annotates each relevant species as ' $\mathrm{S}$ ' for native and 'Offic' for officinal. His introduction explains that officinal is used in the sense of being on the list used for prescriptions that was current at the time.

\section{Project methodology}

My main purpose has been to search for Scottish archaeophytes. I have worked through the species listed by Sutherland and Sibbald noting those that one or other or both had indicated uses and that one or other or both considered native but that I 
would consider as at least possibly introduced. These might well have been naturalised introductions before $1500 \mathrm{AD}$. I have also considered the ornamental plants listed by Sutherland and Sibbald as under cultivation searching for those that are now naturalised in Scotland and likely to be neophytes.

I then turned to the accounts of the species on my list in Lightfoot's Flora Scotica (1777) and Hooker's Flora Scotica (1821), paying particular attention to the habitats listed (Sibbald gives sparse, and sometimes unconvincing, habitat detail for only a proportion of the species listed). If the habitats listed are ruderal, it strengthens the case for considering a species an introduction.

Next I turned to the species captions of the New Atlas (Preston et al., 2002). For many of the species on my list it was clear that the account and the status assigned applied as much to Scotland as to the rest of Britain and Ireland. With a few exceptions, I found myself left with the species that are native in parts of England (usually the south) and introductions in Scotland. These I considered individually.

A much wider perspective is provided by Camilla and James Dickson's Plants and People in Ancient Scotland (Dickson \& Dickson, 2000). This covers the whole period from the Neolithic to the Medieval detailing the archaeological evidence for the plants used by people for food, clothing and medicine. In respect of my project, it is unsurprising that most of the relevant data had been picked up by the species captions of the New Atlas, such as the medicinal use of two undoubted introductions, Atropa belladonna and Hyoscyamus niger, but the confirmation of medicinal use of Malva sy/vestris at Bearsden Fort on the Antonine Wall near Glasgow in the Roman period is especially interesting as the status of the various Malva species has often been debated.

I culled my list further by excluding species which I could accept as native to Scotland, such as Lysimachia vulgaris, or which are not naturalised in Scotland today, such as Leonurus cardiaca.

I have been left with 84 species to consider in depth. These are listed in Appendix 1 at the end of this paper, alongside comments and supporting references where applicable. For the genus Symphytum, similar, but previously unpublished, information is presented below.

\section{Symphytum species as medicinal plants}

Comfrey was used over a long period across much of Europe as a medicinal plant. Extracts of the leaves and roots were used internally to encourage broken bones to set and were used externally to promote the healing of open wounds. The dried roots were sometimes ground to make a coffee substitute. The species most used was Symphytum officinale, but other species seem to have been used locally, especially $S$. tuberosum for which there is support on a number of websites, though I have failed to find an authoritative reference.

Neither Sutherland nor Sibbald claim S. officinale as a native. Its status in Scotland is difficult to fathom. The cream-flowered variety is unambiguous, but it seems to be found only as vegetative patches in widely scattered localities, as at Amelishope NT3016 and Kirkhope Linn NT3823, where it could be a long-established cast-out. Records for the purple-flowered variety are numerous. The early records, as 'var. patens', almost certainly relate to $S$. $x$ uplandicum before its identity was understood. The more recent records are more problematic. I have found that if one 
examines a population of $S$. $x$ uplandicum one often finds much variation in the characters used to separate the two parents. In particular one can find specimens with the strongly decurrent leaves of $S$. officinale. I once took such a specimen to the herbarium of the Royal Botanic Garden, Edinburgh and worked through the Scottish specimens in the folder for $S$. officinale. The relatively few cream-flowered specimens were all satisfactory. A few of the purple-flowered specimens with weakly decurrent leaves were obvious errors for $S . x$ uplandicum. The remainder were problematic. My hunch was that most of them were errors for $S$. $x$ uplandicum, as they had much in common with the specimen I had taken with me, but I was unable to be sure of this.

My opinion is thus that $S$. officinale is a scarce introduction in Scotland and that the records in the BSBI Distribution Database (https://database.bsbi.org/) include many errors. Some of the introductions appear to relate to an early date, making the species an archaeophyte in Scotland.

Sutherland includes $S$. tuberosum in his 1683 catalogue for the Edinburgh Physic Garden. John Hope observed the plant nearby naturalised by the Water of Leith in 1765 where Thomas Yalden also observed it in about 1775 (Pearman, 2017) suggesting that it was brought into cultivation in Edinburgh not long before. It seems inescapable that the species was passed around fairly widely soon afterwards. This hypothesis is supported by records from two eighteenth-century walled gardens in the Scottish Borders. In 2007, I was with a party from the Berwickshire Naturalists' Club on a visit to the fine walled garden of Torwoodlee House NT4738, an eighteenth-century mansion near Galashiels. There was a strong colony of $S$. tuberosum in an uncultivated area. The garden is situated just above the Gala Water and field records follow down the Gala and thence to the River Tweed, where it has colonised the river banks. The walled garden at Thirlestane Castle, Lauder is another case in point. In 2012, I found a strong colony of S. tuberosum by a runnel immediately below the walled garden NT5348. The runnel runs into the Leader Water and again S. tuberosum is naturalised from there to the River Tweed where it is now plentiful on the banks.

The wide ongoing colonisation of the east of Scotland and the Central Belt suggests a series of similar events. On that basis $S$. tuberosum is a neophyte in Scotland and, indeed, in Britain as a whole.

\section{Status changes from the New Atlas proposed by this paper}

The status changes proposed in Appendix 1 may be summarised as follows.

Former culinary plant considered to be an archaeophyte in Scotland: Myrrhis odorata.

Former medicinal plants considered to be archaeophytes in Scotland: Arum maculatum, Atropa belladonna, Betonica officinalis, Bistorta officinalis (Persicaria bistorta), Dipsacus fullonum, Echium vulgare, Hylotelephium telephium (Sedum telephium), Hypericum perforatum, Iris foetidissima, Lactuca virosa, Linaria vulgaris, Marrubium vulgare, Parietaria judaica, Petasites hybridus, Sa/via verbenaca, Scrophularia auriculata, Symphytum officinale, Tanacetum vulgare, Viola odorata. 
Former medicinal plants considered to be archaeophytes in much of Scotland, but locally native: Convallaria majalis, Cynoglossum officinale, Hypericum androsaemum, Malva arborea, Verbascum thapsus.

Former medicinal plants only naturalised after $1500 \mathrm{AD}$, and thus neophytes in Scotland: Daphne laureola, Humulus lupulus, Lysimachia nummularia, Polygonatum multiflorum.

Former medicinal plant considered to be a neophyte in Scotland: Symphytum tuberosum.

Former medicinal plants not naturalised, though sometimes persistent, and thus casual in Scotland: Armoracia rusticana, Inula helenium, Nepeta cataria, Solanum nigrum, Verbena officinalis.

Ornamental plant considered to be a neophyte in much of Scotland, but possibly locally native: Myosotis sy/vatica.

Ornamental plant considered to be a neophyte in Scotland: Geranium lucidum.

Other species considered to be archaeophytes in Scotland: Allium vineale, Convolvulus arvensis, Mycelis muralis.

Other species considered to be neophytes in Scotland: Calystegia sepium, Galium album.

\section{Discussion}

In the Vascular Plant Red Data List for Great Britain (Cheffings \& Farrell, 2005), the editors accept archaeophytes into the class of species to be reviewed for threatened species. They emphasise the cultural and historic importance of archaeophytes. They write: 'Archaeophytes have developed (and exploited) a close relationship with man, which is, in effect, one of commensalism - many archaeophytes are, quite literally, 'followers of man'. The way in which humans now value these species is partly a consequence of having been so intimately associated with them over such a long time period.'

Scotland has a different history and culture from England. This has many subtle effects on its flora and fauna, not least on the archaeophytes which are the main focus of this paper. At a time when Scotland's flora lacks a 'Red Data List' of its own, it is hoped that, by drawing attention to the specifically Scottish archaeophyte element of its flora, its conservation may be better informed.

There is no pretence that the lists of proposed archaeophytes presented here are either comprehensive or infallible. The evidence available is often scanty, and even extensive field experience can only hope to expose a proportion of any fallacies. Nevertheless the majority of the proposals are likely to be uncontroversial.

I have inserted a seemingly disproportionate section on the genus Symphytum. I have done so because the information is unpublished and is a particularly good example of the issues to be addressed in attempting research on archaeophytes. 


\section{References}

Braithwaite, M.E. 2013a. The status of Mycelis muralis in Scotland. BSBI News 122: 19-21.

Braithwaite, M.E. 2013b. Where is Butterbur native in Britain? BSBI News 124: 2326.

Braithwaite, M.E. 2014a. What bindweeds are native in Scotland? BSBI News 126: 13-16.

Braithwaite, M.E. 2014b. Former medicinal plants in: $A$ short Flora of Berwickshire, 131-132. Hawick: privately published. Also available as a pdf at https://bsbi.org/berwickshire

Braithwaite, M.E. 2014c. Species accounts in: A short Flora of Berwickshire, 133-362. Hawick: privately published. Also available as a pdf at https://bsbi.org/berwickshire

Braithwaite, M.E. 2014d. Living plants from ancient people - what do the early introductions into the naturalised flora of Berwickshire tell us about plants cultivated there in the past? History of the Berwickshire Naturalists' Club. 53: 61-78.

Braithwaite, M.E. 2019. Overlooked archaeophytes in the Scottish flora - case studies from the Scottish Borders. BSBI News 142: 17-20.

Braithwaite, M.E. 2020. Patrolling the Scottish Border - plant migration history. British \& Irish Botany 2(4): 335-351. https://doi.org/10.33928/bib.2020.02.335

Cheffings, C.M. \& Farrell, L. (eds.) 2005. The Vascular Plant Red Data List for Great Britain. Peterborough: Joint Nature Conservation Council.

Dickson, C. \& Dickson, J.H. 2000. Plants and People in Ancient Scotland. Stroud: Tempus Publishing.

Hooker, W.J. 1821. Flora Scotica, or a description of Scottish plants. Edinburgh and London: A Constable \& Co, Hurst Robinson \& Co.

Lightfoot, J, 1777. Flora Scotica. London: B. White.

Pearman, D.A. 2017. The Discovery of the Native Flora of Britain \& Ireland. Bristol: Botanical Society of Britain \& Ireland.

Preston, C.D., Pearman, D.A., \& Dines, T.D., eds., 2002. New Atlas of the British and Irish Flora. Oxford: Oxford University Press.

Preston, C.D., Pearman, D.A. \& Hall, A.R. 2004. Archaeophytes in Britain. Botanical Journal of the Linnean Society 145: 257-294.

Ray, J. 1670. Catalogus Plantarum Angliae et insularum adjacentum. London.

Raye, L. 2000. The wild plants of Scotland, the Animals of Scotland (Translation into English of parts of Sibbald's Scotia Illustrata 1684). Cardiff: KDP.

Sibbald, R. 1682. Advertisement: Whereas his sacred Majesty, by his patent, has constituted Sir Robert Sibbald, one of his physicians in ordinary, his geographer of his kingdom of Scotland, and commandeth and ordiaineth him to publish the description of Scotia antiqua. Edinburgh.

Sibbald, R. 1684. Scotia Illustrata: Prodomus Historiae Naturalis. Edinburgh: James Kniblo, Josuah van Solingen \& Jan Colmar.

Stace, C.A. 2010. New Flora of the British Isles, $3^{\text {rd }}$ ed.. Cambridge: Cambridge University Press.

Stace, C.A. 2019. New Flora of the British Isles, $4^{\text {th }}$ ed.. Middlewood Green, Suffolk: C \& M Floristics. 
Sutherland, J. 1683. Hortus medicus Edinburgensis or a catalogue of the plants in the Physical Garden at Edinburgh. Edinburgh: Andrew Anderson.

Copyright retained by author(s). Published by BSBI under the terms of the Creative Commons Attribution 4.0 International Public License.

ISSN: $2632-4970$

https://doi.org/10.33928/bib.2021.03.074 
Appendix 1. Selected species with distribution, uses, proposed status and comments

\begin{tabular}{|c|c|c|c|c|c|c|}
\hline $\begin{array}{c}\text { No. of } \\
\text { tetrads }^{1}\end{array}$ & Taxon $^{2}$ & Uses $^{3}$ & $\begin{array}{c}\text { Native } \\
\text { Suth/Sibb4 }\end{array}$ & $\begin{array}{c}\text { Atlas } \\
\text { status }^{5}\end{array}$ & $\begin{array}{l}\text { Proposed } \\
\text { status }^{6}\end{array}$ & Comments \\
\hline & Useful & & & & & \\
\hline 4,894 & $\begin{array}{l}\text { Aegopodium } \\
\text { podagraria }\end{array}$ & Culinary & Sibbald & Arch & Arch & $\begin{array}{l}\text { Formerly eaten as greens, pernicious } \\
\text { garden weed, minor problem in } \\
\text { riverside woodland }\end{array}$ \\
\hline 81 & $\begin{array}{l}\text { Blitum bonus-henricus } \\
\text { (Chenopodium bonus- } \\
\text { henricus) }\end{array}$ & Culinary & Sibbald & Arch & Arch & $\begin{array}{l}\text { Formerly eaten as greens, persistent } \\
\text { but seldom naturalised }\end{array}$ \\
\hline 1,630 & Myrrhis odorata & Culinary & Sutherland & & Arch & $\begin{array}{l}\text { Formerly used as a flavouring, } \\
\text { persistent and sometimes naturalised } \\
\text { along rivers (Braithwaite, 2020) }\end{array}$ \\
\hline 113 & Borago officinalis & Culinary & & Neo & Neo & $\begin{array}{l}\text { Used in salads, recently grown as a } \\
\text { crop for oils }\end{array}$ \\
\hline 551 & Reseda luteola & Dye & Sutherland & Arch & Arch & $\begin{array}{l}\text { Formerly used as a dye, now } \\
\text { naturalised on dry banks (Braithwaite, } \\
2014 b \text { ) }\end{array}$ \\
\hline 27 & Artemisia absinthium & Medicinal & Sutherland & Arch & Arch & $\begin{array}{l}\text { Former medicinal uses, a few } \\
\text { naturalised colonies }\end{array}$ \\
\hline 857 & Artemisia vulgaris & Medicinal & Sutherland & Arch & Arch & $\begin{array}{l}\text { Former medicinal uses, widespread } \\
\text { ruderal }\end{array}$ \\
\hline 450 & Arum maculatum & Medicinal & Sutherland & Intro & Arch & $\begin{array}{l}\text { Former medicinal uses but dangerous, } \\
\text { often introduced as a curiosity and } \\
\text { naturalised (Braithwaite, 2020) }\end{array}$ \\
\hline 13 & Atropa belladonna & Medicinal & Sibbald & Intro & Arch & $\begin{array}{l}\text { Former medicinal uses, but very } \\
\text { dangerous poison (Dickson \& } \\
\text { Dickson, 2000) }\end{array}$ \\
\hline
\end{tabular}




\begin{tabular}{|c|c|c|c|c|c|c|}
\hline 41 & Ballota nigra & Medicinal & Sibbald & Arch & Arch & $\begin{array}{l}\text { Former medicinal uses, herbal tea, } \\
\text { naturalised in grassland (Braithwaite, } \\
\text { 2014b) }\end{array}$ \\
\hline 86 & Betonica officinalis & Medicinal & Sutherland & Natur & Arch & $\begin{array}{l}\text { Former medicinal uses, very locally } \\
\text { naturalised, now introduced in } \\
\text { wildflower sowings (Braithwaite, } \\
\text { 2020) }\end{array}$ \\
\hline 108 & Chelidonium majus & Medicinal & & Arch & Arch & $\begin{array}{l}\text { Former medicinal uses, narrowly } \\
\text { naturalised about habitation }\end{array}$ \\
\hline 387 & Conium maculatum & Medicinal & Sibbald & Arch & Arch & $\begin{array}{l}\text { Former medicinal uses, widespread } \\
\text { ruderal (Braithwaite, 2014b) }\end{array}$ \\
\hline 80 & Descurainia sophia & Medicinal & Sibbald & Arch & Arch & $\begin{array}{l}\text { Former medicinal uses, scarce arable } \\
\text { weed and ruderal }\end{array}$ \\
\hline 428 & Dipsacus fullonum & Medicinal & Sutherland & $\begin{array}{l}\text { Natur or } \\
\text { Alien }\end{array}$ & Arch & $\begin{array}{l}\text { Former medicinal uses, naturalised on } \\
\text { dry banks, also introduced as an } \\
\text { ornamental (Braithwaite, 2020) }\end{array}$ \\
\hline 272 & Echium vulgare & Medicinal & Sutherland & Natur & Arch & $\begin{array}{l}\text { Former medicinal uses, naturalised on } \\
\text { rock and in ruderal habitats } \\
\text { (Braithwaite, 2014b) }\end{array}$ \\
\hline 133 & Erysimum cheiri & Medicinal & Sibbald & Arch & Arch & $\begin{array}{l}\text { Former medicinal uses, naturalised on } \\
\text { walls }\end{array}$ \\
\hline 11 & Hyoscyamus niger & Medicinal & Sutherland & Arch & Arch & $\begin{array}{l}\text { Former medicinal uses, very } \\
\text { persistent as buried seed on dry } \\
\text { banks (Braithwaite, 2014b, Dickson \& } \\
\text { Dickson 2000) }\end{array}$ \\
\hline 1,201 & Hypericum perforatum & Medicinal & Sutherland & Natur & Arch & $\begin{array}{l}\text { Former medicinal uses, introduced } \\
\text { widely in the distant past, naturalised } \\
\text { along rivers and later plentiful on } \\
\text { railway ballast (Braithwaite, 2014b, } \\
2019 \text { ) }\end{array}$ \\
\hline
\end{tabular}




\begin{tabular}{|c|c|c|c|c|c|c|}
\hline 66 & Iris foetidissima & Medicinal & Sibbald & Intro & Arch & $\begin{array}{l}\text { Former medicinal uses, very narrowly } \\
\text { naturalised }\end{array}$ \\
\hline 38 & Lactuca virosa & Medicinal & Sutherland & Natur & Arch & $\begin{array}{l}\text { Former medicinal uses, has the } \\
\text { appearance of a native on south- } \\
\text { facing sandstone rocks, but probably } \\
\text { naturalised (Braithwaite, } 2014 b \text { ) }\end{array}$ \\
\hline 1,116 & Lamium album & Medicinal & Sutherland & Arch & Arch & $\begin{array}{l}\text { Former medicinal uses, also leaves } \\
\text { eaten as greens and flowers used to } \\
\text { make a cosmetic, naturalised near } \\
\text { habitation and on river banks }\end{array}$ \\
\hline 489 & Linaria vulgaris & Medicinal & Sutherland & Natur & Arch & $\begin{array}{l}\text { Former medicinal uses, many of the } \\
\text { Scottish populations represent } \\
\text { colonisation of railway ballast } \\
\text { (Braithwaite, 2019) }\end{array}$ \\
\hline 412 & Malva moschata & Medicinal & & Arch & Arch & $\begin{array}{l}\text { Former medicinal uses, mostly } \\
\text { ruderal, rarely in natural grassland, } \\
\text { frequent outcast from gardens }\end{array}$ \\
\hline 47 & Malva neglecta & Medicinal & Sibbald & Arch & Arch & $\begin{array}{l}\text { Former medicinal uses, ruderal } \\
\text { habitats }\end{array}$ \\
\hline 252 & Malva sylvestris & Medicinal & Sutherland & Arch & Arch & $\begin{array}{l}\text { Former medicinal uses, ruderal } \\
\text { habitats (Braithwaite, 2014b, Dickson } \\
\text { \& Dickson 2000) }\end{array}$ \\
\hline 4 & Marrubium vulgare & Medicinal & Sutherland & Intro & Arch & $\begin{array}{l}\text { Former medicinal uses, persistent } \\
\text { colonies on Lothian coast }\end{array}$ \\
\hline 20 & Onopordum acanthium & Medicinal & & Arch & Arch & $\begin{array}{l}\text { Former medicinal uses, mostly casual, } \\
\text { some recent garden introductions }\end{array}$ \\
\hline 106 & Parietaria judaica & Medicinal & Sutherland & $\begin{array}{l}\text { Natur } \\
\text { and } \\
\text { Intro }\end{array}$ & Arch & $\begin{array}{l}\text { Former medicinal uses, well } \\
\text { naturalised on walls and old buildings }\end{array}$ \\
\hline 487 & Bistorta officinalis & Medicinal & Sutherland & Natur & Arch & Former medicinal uses, very \\
\hline
\end{tabular}




\begin{tabular}{|c|c|c|c|c|c|c|}
\hline & (Persicaria bistorta) & & & $\begin{array}{l}\text { and } \\
\text { Intro }\end{array}$ & & $\begin{array}{l}\text { persistent colonies in grassland, } \\
\text { usually near habitation }\end{array}$ \\
\hline 1,183 & Petasites hybridus & Medicinal & Sutherland & $\begin{array}{l}\text { Natur } \\
\text { and } \\
\text { Intro }\end{array}$ & Arch & $\begin{array}{l}\text { Former medicinal uses, very widely } \\
\text { naturalised, mainly by watercourses, } \\
\text { often traceable upstream to an } \\
\text { introduction point (Braithwaite, } \\
\text { 2013b) }\end{array}$ \\
\hline 15 & Sambucus ebulus & Medicinal & Sibbald & Arch & Arch & $\begin{array}{l}\text { Former medicinal uses, rare as } \\
\text { persistent colonies near habitation }\end{array}$ \\
\hline 122 & Saponaria officinalis & Medicinal & & Arch & Arch & $\begin{array}{l}\text { Former medicinal uses, narrowly } \\
\text { naturalised about habitation }\end{array}$ \\
\hline 168 & Scrophularia auriculata & Medicinal & Sutherland & Natur & Arch & $\begin{array}{l}\text { Former medicinal uses, before recent } \\
\text { introductions only along a few } \\
\text { watercourses in the Central Belt }\end{array}$ \\
\hline 501 & $\begin{array}{l}\text { Hylotelephium } \\
\text { telephium (Sedum } \\
\text { telephium) }\end{array}$ & Medicinal & Sutherland & $\begin{array}{l}\text { Natur } \\
\text { and } \\
\text { Intro }\end{array}$ & Arch & $\begin{array}{l}\text { Former medicinal uses, narrowly } \\
\text { naturalised about habitation }\end{array}$ \\
\hline 19 & Silybum marianum & Medicinal & Sutherland & Arch & Arch & $\begin{array}{l}\text { Former medicinal uses, very locally } \\
\text { naturalised along river banks }\end{array}$ \\
\hline 34 & Smyrnium olusatrum & Medicinal & Sibbald & Arch & Arch & $\begin{array}{l}\text { Former medicinal uses, mainly as } \\
\text { persistent castout }\end{array}$ \\
\hline 283 & Symphytum officinale & Medicinal & & $\begin{array}{l}\text { Natur } \\
\text { and } \\
\text { Intro }\end{array}$ & Arch & $\begin{array}{l}\text { Former medicinal uses, before recent } \\
\text { introductions mainly along a few } \\
\text { watercourses in the Central Belt, } \\
\text { much confusion with } S . x \text { uplandicum } \\
\text { (see also main text) }\end{array}$ \\
\hline 1,104 & $\begin{array}{l}\text { Tanacetum } \\
\text { parthenium }\end{array}$ & Medicinal & & Arch & Arch & $\begin{array}{l}\text { Former medicinal uses, widely } \\
\text { naturalised about towns and villages }\end{array}$ \\
\hline 920 & Tanacetum vulgare & Medicinal & Sutherland & $\begin{array}{l}\text { Natur } \\
\text { and }\end{array}$ & Arch & $\begin{array}{l}\text { Former medicinal uses, persistent } \\
\text { colonies near habitation, naturalised }\end{array}$ \\
\hline
\end{tabular}




\begin{tabular}{|c|c|c|c|c|c|c|}
\hline & & & & Intro & & along river banks (Braithwaite, 2019) \\
\hline 431 & Urtica urens & Medicinal & Sutherland & Arch & Arch & $\begin{array}{l}\text { Former medicinal uses, in old gardens } \\
\text { and under trees in cattle-grazed } \\
\text { parks, seldom as an arable weed }\end{array}$ \\
\hline 134 & Viola odorata & Medicinal & Sibbald & Intro & Arch & $\begin{array}{l}\text { Former medicinal uses, naturalised } \\
\text { near habitation under trees and } \\
\text { hedges }\end{array}$ \\
\hline 116 & Convallaria majalis & Medicinal & Sibbald & $\begin{array}{l}\text { Natur } \\
\text { and } \\
\text { Intro }\end{array}$ & $\begin{array}{l}\text { Natur and } \\
\text { Arch }\end{array}$ & $\begin{array}{l}\text { Former medicinal uses, rare native, } \\
\text { most records are narrowly naturalised } \\
\text { introductions }\end{array}$ \\
\hline 20 & Cynoglossum officinale & Medicinal & Sutherland & $\begin{array}{l}\text { Natur or } \\
\text { Alien }\end{array}$ & $\begin{array}{l}\text { Natur and } \\
\text { Arch }\end{array}$ & $\begin{array}{l}\text { Former medicinal uses, rare in natural } \\
\text { habitats, more frequent in } \\
\text { anthropomorphic habitats }\end{array}$ \\
\hline 1,840 & $\begin{array}{l}\text { Hypericum } \\
\text { androsaemum }\end{array}$ & Medicinal & & $\begin{array}{l}\text { Natur } \\
\text { and } \\
\text { Intro }\end{array}$ & $\begin{array}{l}\text { Natur and } \\
\text { Arch }\end{array}$ & $\begin{array}{l}\text { Former medicinal uses, native in } \\
\text { western Scotland, introduced and } \\
\text { naturalised in the east }\end{array}$ \\
\hline 45 & Malva arborea & Medicinal & Sutherland & $\begin{array}{l}\text { Natur } \\
\text { and } \\
\text { Intro }\end{array}$ & $\begin{array}{l}\text { Natur and } \\
\text { Arch }\end{array}$ & $\begin{array}{l}\text { Former medicinal uses, apparently a } \\
\text { rare native on the coast, introduced } \\
\text { elsewhere }\end{array}$ \\
\hline 647 & Verbascum thapsus & Medicinal & Sibbald & $\begin{array}{l}\text { Natur } \\
\text { and } \\
\text { Intro }\end{array}$ & $\begin{array}{l}\text { Natur and } \\
\text { Arch }\end{array}$ & $\begin{array}{l}\text { Former medicinal uses, frequent in } \\
\text { anthropomorphic habitats, arguably } \\
\text { not native }\end{array}$ \\
\hline 105 & Daphne laureola & Medicinal & & Intro & Neo & $\begin{array}{l}\text { Former medicinal uses, more recently } \\
\text { naturalised on steep banks in } \\
\text { riverside woodland }\end{array}$ \\
\hline 589 & $\begin{array}{l}\text { Doronicum } \\
\text { pardalianches }\end{array}$ & Medicinal & & Neo & Neo & $\begin{array}{l}\text { Former medicinal uses, more recently } \\
\text { a pestilential colonist of woodland } \\
\text { near habitation }\end{array}$ \\
\hline 120 & Humulus lupulus & Medicinal & & Intro & Neo & $\begin{array}{l}\text { Former medicinal uses, not a } \\
\text { commercial crop in Scotland, }\end{array}$ \\
\hline
\end{tabular}




\begin{tabular}{|c|c|c|c|c|c|c|}
\hline & & & & & & persistent casual \\
\hline 257 & $\begin{array}{l}\text { Lysimachia } \\
\text { nummularia }\end{array}$ & Medicinal & & Intro & Neo & $\begin{array}{l}\text { Former medicinal uses, sparsely } \\
\text { naturalised, usually in damp grassland }\end{array}$ \\
\hline 47 & $\begin{array}{l}\text { Polygonatum } \\
\text { multiflorum }\end{array}$ & Medicinal & & Intro & $\mathrm{NeO}$ & $\begin{array}{l}\text { Former medicinal uses, narrowly } \\
\text { naturalised on road verges and in } \\
\text { woodland about habitation }\end{array}$ \\
\hline 84 & $\begin{array}{l}\text { Petrosedum rupestre } \\
\text { (Sedum rupestre) }\end{array}$ & Medicinal & Sibbald & Neo & $\mathrm{NeO}$ & $\begin{array}{l}\text { Former medicinal uses, naturalised on } \\
\text { walls }\end{array}$ \\
\hline 30 & $\begin{array}{l}\text { Sempervivum } \\
\text { tectorum }\end{array}$ & Medicinal & Sutherland & Neo & Neo & $\begin{array}{l}\text { Former medicinal uses, narrowly } \\
\text { naturalised on old walls and houses }\end{array}$ \\
\hline 108 & Solanum nigrum & Medicinal & & Intro & $\mathrm{NeO}$ & $\begin{array}{l}\text { Former medicinal uses, rare casual } \\
\text { with persistent seedbank, sometimes } \\
\text { introduced with crops }\end{array}$ \\
\hline 1,596 & $\begin{array}{l}\text { Symphytum } \\
\text { tuberosum }\end{array}$ & Medicinal & & $\begin{array}{l}\text { Possibly } \\
\text { Natur }\end{array}$ & Neo & $\begin{array}{l}\text { Former medicinal uses, naturalised by } \\
\text { the Water of Leith by } 1675 \text {, grown in } \\
\text { the Edinburgh Physic Garden in 1683, } \\
\text { and then introduced widely and } \\
\text { naturalised along rivers (Braithwaite, } \\
\text { 2014c, Pearman 2017, see also main } \\
\text { text) }\end{array}$ \\
\hline 72 & Armoracia rusticana & Medicinal & & Arch & $\begin{array}{l}\text { Not } \\
\text { naturalised }\end{array}$ & $\begin{array}{l}\text { Former medicinal uses, also culinary, } \\
\text { persistent castout }\end{array}$ \\
\hline 75 & Inula helenium & Medicinal & & Arch & $\begin{array}{l}\text { Not } \\
\text { naturalised }\end{array}$ & $\begin{array}{l}\text { Former medicinal uses, persistent } \\
\text { castout }\end{array}$ \\
\hline 2 & Nepeta cataria & Medicinal & & Arch & $\begin{array}{l}\text { Not } \\
\text { naturalised }\end{array}$ & $\begin{array}{l}\text { Former medicinal uses, persistent } \\
\text { castout }\end{array}$ \\
\hline 2 & Salvia verbenaca & Medicinal & Sutherland & Intro & $\begin{array}{l}\text { Not } \\
\text { naturalised }\end{array}$ & $\begin{array}{l}\text { Former medicinal uses, formerly } \\
\text { naturalised in a few places }\end{array}$ \\
\hline 5 & Verbena officinalis & Medicinal & Sutherland & Arch & $\begin{array}{l}\text { Not } \\
\text { naturalised }\end{array}$ & $\begin{array}{l}\text { Former medicinal uses, persistent } \\
\text { castout }\end{array}$ \\
\hline
\end{tabular}




\begin{tabular}{|c|c|c|c|c|c|c|}
\hline & & & & & & \\
\hline & Ornamental & & & & & \\
\hline 195 & Aconitum napellus & Ornamental & & Neo & $\mathrm{Neo}$ & $\begin{array}{l}\text { Ornamental, quite well naturalised } \\
\text { about houses and villages }\end{array}$ \\
\hline 143 & Antirrhinum majus & Ornamental & & Neo & $\mathrm{Neo}$ & $\begin{array}{l}\text { Ornamental, mainly found on old } \\
\text { walls and buildings }\end{array}$ \\
\hline 823 & Aquilegia vulgaris & Ornamental & & Natur & $\mathrm{Neo}$ & $\begin{array}{l}\text { Ornamental, native in England but not } \\
\text { Scotland, quite well naturalised about } \\
\text { houses and villages }\end{array}$ \\
\hline 534 & Centaurea montana & Ornamental & & Neo & $\mathrm{Neo}$ & $\begin{array}{l}\text { Ornamental, forms large persistent } \\
\text { colonies where cast out }\end{array}$ \\
\hline 234 & Centranthus ruber & Ornamental & & $\mathrm{Neo}$ & $\mathrm{Neo}$ & $\begin{array}{l}\text { Ornamental, naturalised on old walls } \\
\text { and coastal habitats }\end{array}$ \\
\hline 453 & Geranium lucidum & Ornamental & Sutherland & $\begin{array}{l}\text { Natur or } \\
\text { Alien }\end{array}$ & $\mathrm{Neo}$ & $\begin{array}{l}\text { Probably introduced as an } \\
\text { ornamental, only naturalised near } \\
\text { habitation, date of introduction very } \\
\text { uncertain }\end{array}$ \\
\hline 988 & Hesperis matronalis & Ornamental & & Neo & $\mathrm{Neo}$ & $\begin{array}{l}\text { Ornamental, widely naturalised, } \\
\text { especially on shady riverside banks }\end{array}$ \\
\hline 1,686 & $\begin{array}{l}\text { Hyacinthoides } \\
\text { hispanica sens. lat. }\end{array}$ & Ornamental & & $\mathrm{Neo}$ & $\mathrm{Neo}$ & $\begin{array}{l}\text { Ornamental, distribution includes } H \cdot x \\
\text { massartiana }\end{array}$ \\
\hline 74 & Lilium martagon & Ornamental & & $\mathrm{Neo}$ & $\mathrm{Neo}$ & $\begin{array}{l}\text { Ornamental, very locally naturalised } \\
\text { in woodland }\end{array}$ \\
\hline 541 & Linaria purpurea & Ornamental & & Neo & $\mathrm{Neo}$ & $\begin{array}{l}\text { Ornamental, widely naturalised about } \\
\text { towns and villages }\end{array}$ \\
\hline 834 & Myosotis sy/vatica & Ornamental & & $\begin{array}{l}\text { Natur } \\
\text { and } \\
\text { Intro }\end{array}$ & $\mathrm{Neo}$ & $\begin{array}{l}\text { Ornamental, arguably native in some } \\
\text { places, but mainly introduced and } \\
\text { naturalised (Braithwaite, 2020) }\end{array}$ \\
\hline 497 & $\begin{array}{l}\text { Ornithogalum } \\
\text { umbellatum sens. lat. }\end{array}$ & Ornamental & & Neo & $\mathrm{Neo}$ & $\begin{array}{l}\text { Ornamental, becoming increasingly } \\
\text { naturalised along road verges near }\end{array}$ \\
\hline
\end{tabular}




\begin{tabular}{|c|c|c|c|c|c|c|}
\hline & & & & & & habitation \\
\hline 983 & $\begin{array}{l}\text { Pentaglottis } \\
\text { sempervirens }\end{array}$ & Ornamental & & $\mathrm{NeO}$ & $\mathrm{Neo}$ & $\begin{array}{l}\text { Ornamental, widely naturalised, } \\
\text { especially on sunny riverside banks }\end{array}$ \\
\hline 422 & Petasites albus & Ornamental & & Neo & $\mathrm{Neo}$ & $\begin{array}{l}\text { Ornamental, widely naturalised along } \\
\text { rivers }\end{array}$ \\
\hline 855 & Sambucus racemosa & Ornamental & & Neo & $\mathrm{Neo}$ & $\begin{array}{l}\text { Ornamental, widely naturalised in } \\
\text { woodland and occasionally moorland }\end{array}$ \\
\hline 24 & Symphytum orientale & Ornamental & & Neo & $\mathrm{Neo}$ & $\begin{array}{l}\text { Ornamental, narrowly naturalised } \\
\text { near habitation }\end{array}$ \\
\hline 15 & Tulipa sylvestris & Ornamental & & $\mathrm{NeO}$ & $\mathrm{NeO}$ & $\begin{array}{l}\text { Ornamental, a few large naturalised } \\
\text { colonies in woodland near gardens }\end{array}$ \\
\hline \multirow[t]{3}{*}{41} & Verbascum nigrum & Ornamental & & Intro & $\mathrm{Neo}$ & $\begin{array}{l}\text { Ornamental, date of introduction very } \\
\text { uncertain, narrowly naturalised in } \\
\text { ruderal habitats in towns and villages }\end{array}$ \\
\hline & & & & & & \\
\hline & Other & & & & & \\
\hline 172 & Allium vineale & Other & Sutherland & Natur & Arch & $\begin{array}{l}\text { Not an arable weed in Scotland, } \\
\text { probably introduced with construction } \\
\text { materials, now naturalised in } \\
\text { grassland, especially along rivers }\end{array}$ \\
\hline 224 & Convolvulus arvensis & Other & Sutherland & Natur & Arch & $\begin{array}{l}\text { Not an arable weed in Scotland, } \\
\text { probably introduced to gardens with } \\
\text { cultivated plants and later along } \\
\text { railway ballast (Braithwaite, 2014a) }\end{array}$ \\
\hline 409 & Mycelis muralis & Other & & $\begin{array}{l}\text { Natur } \\
\text { exc. } \\
\text { Ireland }\end{array}$ & Arch & $\begin{array}{l}\text { Probably introduced with construction } \\
\text { materials, now naturalised on walls } \\
\text { and in woodland (Braithwaite, 2013a) }\end{array}$ \\
\hline 1,866 & Calystegia sepium & Other & Sibbald & Natur & $\mathrm{Neo}$ & $\begin{array}{l}\text { Probably introduced with hedging } \\
\text { stock and now widely naturalised } \\
\text { (Braithwaite, 2014a) }\end{array}$ \\
\hline
\end{tabular}




\begin{tabular}{|l|l|l|l|l|l|l|}
\hline 291 & Galium album & Other & Sutherland & Natur & Neo & $\begin{array}{l}\text { There is a thin scatter of records } \\
\text { which may relate to ancient chance } \\
\text { introductions, but most populations } \\
\text { are along railways or otherwise } \\
\text { associated with man's recent activities } \\
\text { (Braithwaite, 2020) }\end{array}$ \\
\hline
\end{tabular}

${ }^{1}$ Number of tetrads in Scotland 2000-2019 using data extracted from the Botanical Society of the Britain and Ireland Distribution Database (https://database.bsbi.org/) in October 2020. There are close to 20,000 tetrads ( $2 \times 2 \mathrm{~km}$ grid squares) in Scotland.

${ }^{2}$ Plant names follow Stace (2019) with any older names in Stace (2010) shown in parentheses

3 Uses categorised as culinary, dye, medicinal, ornamental or other

${ }^{4}$ Taxa considered native by Sutherland (1683) or, if not, considered native by Sibbald (1684)

${ }^{5}$ Status given in the New Atlas of the British and Irish Flora (Preston et al., 2002) (Arch = archaeophyte, Neo = neophyte, Intro = introduced, Natur $=$ naturalised)

${ }^{6}$ Status proposed in this paper 